\title{
USE OF AIRBORNE LASER SCANNING (ALS) FOR 3D MODELLING IN DENSE URBAN AREAS (OLD ISLAMIC PART OF FATIMID CAIRO - EGYPT)
}

\author{
H. M. Gadou \\ Ain Shams University, Faculty of Engineering, \\ Dept. of Urban Design \& Planning, Cairo, Egypt;
}

\begin{abstract}
Cairo is one of the largest heritage cities in the world. It is a multi-cultural city where various cultural groups live. The Ministry of Culture in Egypt works towards protecting the multicultural life in the city by ensuring a healthy socio-cultural environment. However, the reality is very complex. As a matter of fact there is not enough spatial information in terms of maps on the social geography of the city. Whatever information is available is not up-todate. Virtual studies or documentations are very poor.
\end{abstract}

This paper tries, first, to review these upgrading or rehabilitation events for old Cairo from many different planning perspective and its input; and second, to explain why Laser scanning technology should be chosen for collecting up-to-date laser data (Digital Elevation Model DEM) for the purpose of upgrading the old Islamic part of Cairo. The paper tries also to explain the steps that were followed in carrying out a pilot project "Laser scanning for the old Cairo".

The data obtained through laser scanning were used to indicate ways and means towards enhancing the multicultural and traditional life style without any negative impact. The paper also identifies benefits as well as the problems encountered in the project.

KEY WORDS: Airborne Laser Scanning (ALS), DSM, DEM, 3D Modeling, Mapping, Old City Upgrading or Rehabilitation, 3D Visualization.

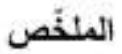

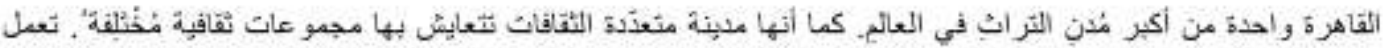

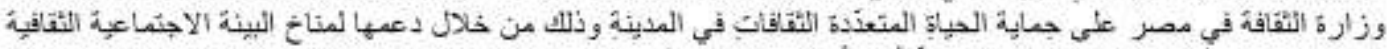

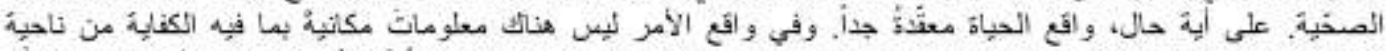

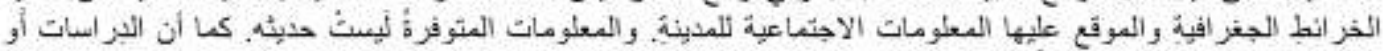

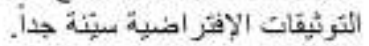

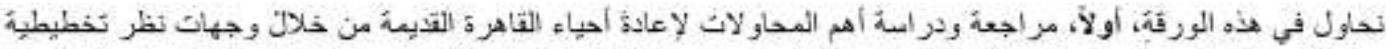

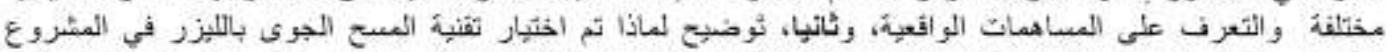

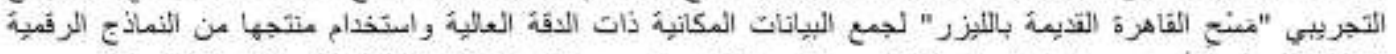

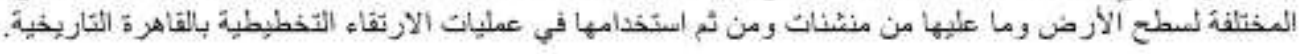

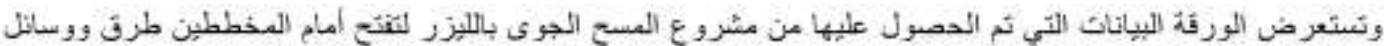

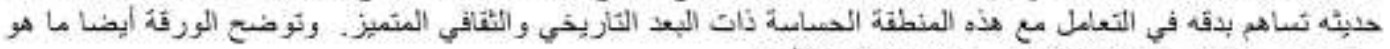

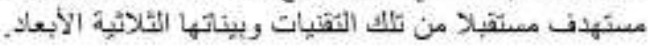




\section{INTRODUCTION}

\subsection{Historical Introduction :Fatimid Cairo: Al-Qahira}

Cairo is the capital of Egypt and the largest city in Africa, its name means "the victorious city". "The Fatimids" (descendants of the Prophet's daughter Fatima and her husband Ali) founded al-Qahira shortly after the taking of Fustat in 969. AlQahira was designed to house only the governing elite; the population of Fustat was not initially allowed to settle here. As Shia Muslims, the ruling dynasty held different religious views to the Sunni Egyptian population. Al-Qahira, the area of modern Cairo which is now called 'Islamic', formed the centre of the city up until the midnineteenth century.

Islamic Cairo, perhaps more properly thought of as medieval Cairo, is an area of narrow streets, covered markets and crumbling old buildings. Of all Cairo, this quarter most evokes its past, and in many ways has changed little. It has inspired many writings, from Arabian Nights to the works of the modern Nobel laureate Naguib Mahfouz. Getting lost amongst the winding alleys is almost inevitable and even enjoyable.

'Islamic Cairo' is a strange phrase. Egypt is of course a Muslim country. By using that phrase we are referring to the historic eastern sections of the city, spreading between the faded splendor of 19th-century downtown and the Muqqatam Hills.

Figure (1) Layout of Islamic Cairo.

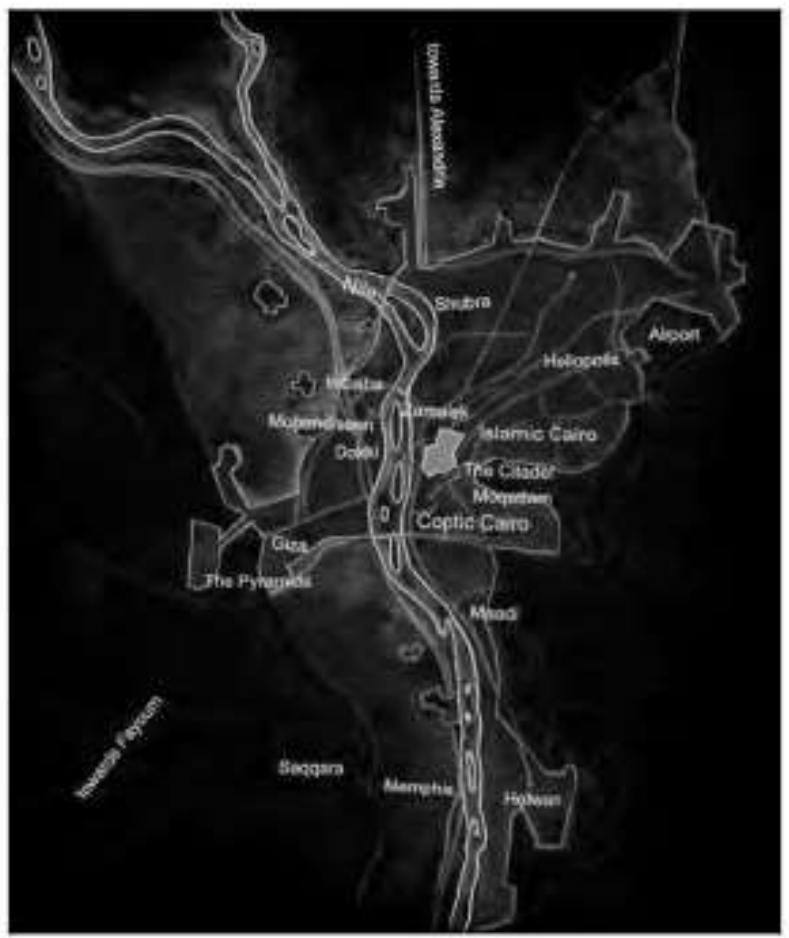

Source: Egyptian Cuiture Ministry web page 
This is the area nominated as a World Heritage Site by UNESCO, where streets are unpaved, mosques and 'madrassas' cluster thickly, and life within the great city walls seemingly continues much as it did under the Mamlukes. Cairo is Islamic, though some areas are more than others. Actually, this area is no more Islamic than Central Cairo, but as though walking through a time machine, we are transported back to Cairo's past Islamic heritage, to a world of ancient mosques and 1,500 hundred year old markets; to medieval forts and the city that was Salah ad-Din's.

\subsection{Technical Introduction}

The technical importance of this project coming from that this is the first project done (July 1999) with laser scanning in this part of the word. This project came as a joint venture work*, to transfer the hi-technology (ALS) from Germany to Egypt. We plan to use this technique in civil branch to support the urban planning projects in Egypt, especially in the areas in which are very hard to get up to date spatial information. The author of this paper was the technical manager for this transfer project. He started the work in Germany in 1997 and continued at NARSS in Cairo from Feb. 1998 until July 1999.

The ALS system used in this pilot project was the first version of the "TopoSys fiber scanner" accomplished by a camera. From airplane the LIDAR system basically captured three types of data: Laser, GPS, and INS (Inertial Navigation System) data.

\section{CAIRO'S LAYOUT, MOVEMENT \& CHARACTERISTICS}

Old Cairo or Medieval Cairo has historical precursors at somewhat different geographical locations, in part explained by the changed channel of the Nile which formerly flowed much closer to Old Cairo. Pharaonic Memphis and On (Heliopolis) were located in some distance to the south and north-east of present-day Cairo.

A more immediate and geographically closer precursor was pre-Arab and pre-Muslim Cairo, called Misr-al-Fustat or Al-Khalifa, now known as Coptic Cairo. This settlement was also occupied and fortified by the Romans. To the north-east of what are now the ruins of Fustat, the Fatimids established the walled palace city of Al Qahira in about 1000 AD. By 1500 AD, Al Qahira or Fatimid Cairo had spread southwards and westwards to cover the area, now generally regarded as Old Cairo. Two related urban features should be noted.

To the east and south, extensive medieval cemeteries, now known collectively as the Cities of the Dead, were developed to provide burial sites for Fustat and Al Qahira. Secondly, the port outlier of Bulaq was developed on the eastern bank of the Nile, and this district is still distinctive today as morphologically reassembling Old Cairo, despite lying just north of the present-day Central Business District of modern Cairo.

\footnotetext{
* by National Authority for Remote Sensing and Space Science (NARSS), Egypt, and Institute for Photogrammetry (ifp), University of Stuttgart, Germany
} 
Figure (2) Street pattern of Old Cairo, 1798 and 1978

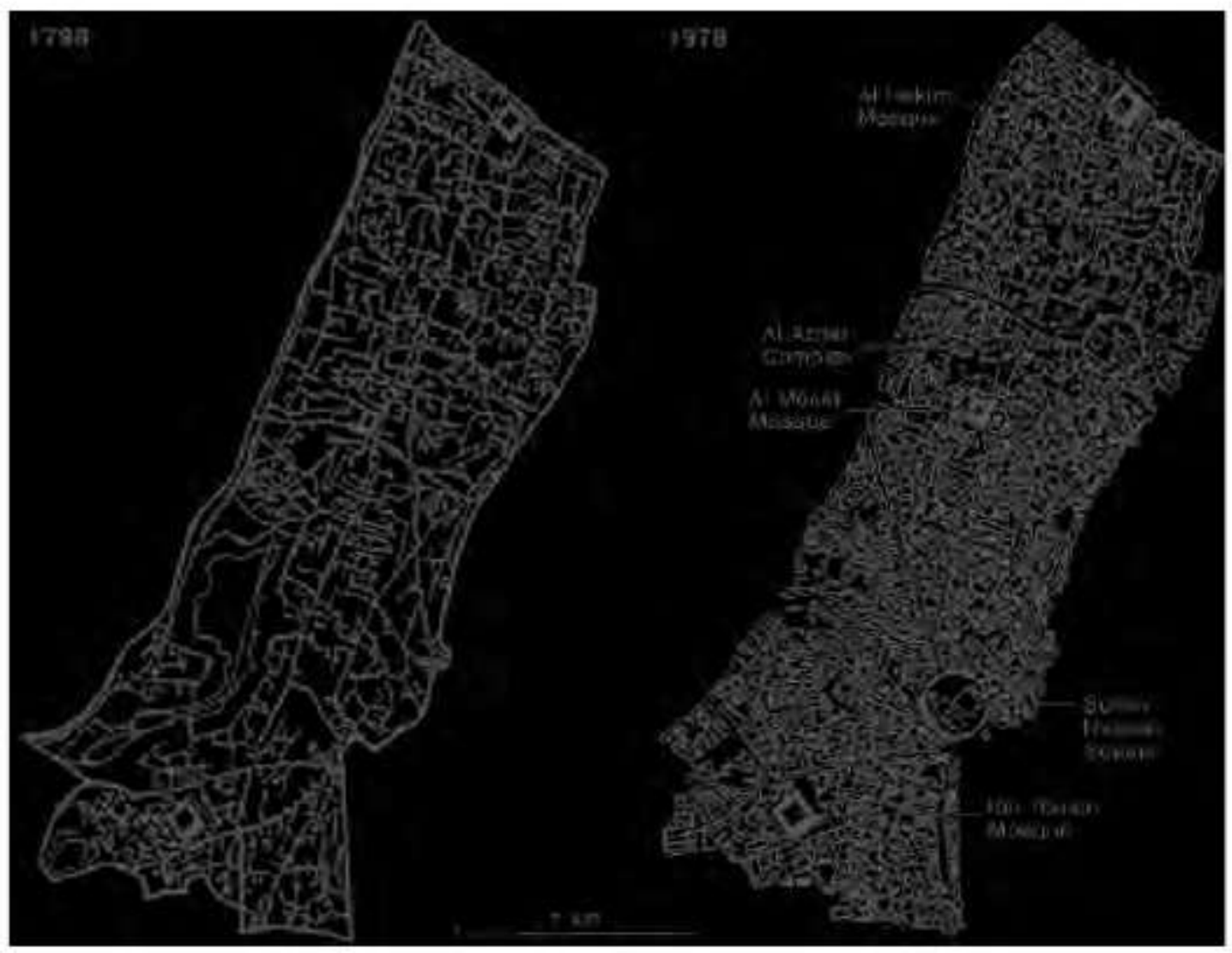

Source: after UNDP (1997)

During the 19th and early 20th centuries, Cairo extended northwards and westwards of Old Cairo, often on reclaimed land close to the Nile as in the case of Garden City and the Tahrir Square city centre area.

Late 20th-century urban growth has left Old Cairo as a relatively small portion of the sprawling metropolis of $10 \ldots 12$ million people (1996 census figures), small in area and population terms, but of major importance in terms of cultural and heritage. So, Old Cairo is larger in area than Fatimid or Medieval Cairo. Ahmed and Kamel (1996) divide Cairo up into three 'cities': Medieval Cairo, European Cairo and Contemporary Cairo.

Their 'Islamic or Medieval Cairo (969-1863 AD)' closely approximates the Old Cairo described above and, as the accompanying dates suggest, covers the area built up during the Fatimid, Ayyubid, Mamluk, Ottoman, French expedition and even Mohamed Ali periods. They argue that urban development during these successive eras "together led to the establishment of Islamic Cairo y all based conceptually on Islamic urban patterns" (Ahmed \& Kamel, 1996, p. 105). 
Perhaps an alternative nomenclature to 'Old Cairo' or 'Medieval Cairo' could be 'preEuropeanised Cairo', which delimits its street pattern and layout from the strongly European influenced 19th-century layout and buildings of Mohamed Ali's period and later. To a large extent 'pre-Europeanised Cairo' equates to the built-up area surveyed by Napoleon's occupying forces, 1798-1801, and depicted in their resulting fascinating map dated 1800 (Description de l'Egypte, 1809).

Many elements of the original street pattern as surveyed in 1798-1800 are still evident in the present (1978) layout and morphology of Old Cairo (Fig. 2), except from the construction of two major new streets cutting across the old urban fabric, namely Al Azhar street in the north and the straight Mohamed Ali street further south linking Sultan Hussain mosque and 19thcentury Cairo. The north-south AlMu'izz street continues to be the main axis articulating the Old City.

Also, a lot of buildings are relatively recent, as during the late 19th century and first half of the 20th century a lot of old traditional buildings in Old Cairo were replaced by more modern single- and two-storey buildings. The urban fabric was thus 'modernised' but only within the long-established street pattern and the old landownership framework (Salin, 1996; llbert, 1982). This has been demonstrated for the 1990 s by Aboukorah (1995) for the Al-Ghuriya quarter where, despite the permanency of the street pattern, numerous new buildings of sometimes up to 8 or 10 storeys have been constructed. Other older buildings have been modified by adding further storeys, all of which serves to further overstrain the poor water supply and sewerage systems. (K. Sutton, W. Fahmi / Habitat International 26 (2002) 73-93 79)

\section{REHABILITATION EVENTS FOR OLD CAIRO}

Cairo's post-1800 'European-style' urban development to the west and north of the original 'Fatimid' Cairo contrasts sharply with the earlier traditional 'Islamic' street layout and vernacular buildings. Also, during the 19 th century many administrative and Central Business District functions migrated out to this 19th and early 20th century extension of the city, built in part on the Haussman-like lines of 19th-century Paris. (URBAMA, 'Urbanisation du Monde Arabe') (Ilbert, 1982; Meyer, 1988) often include research on Old Cairo, clearly interpreting it as the academic equivalent.

Similarly, Abu-Lughod (1971) uses the medina model to good effect in her magisterial study of Cairo. Furthermore, the UNESCO has designated Old Cairo as a World Heritage Site.

\subsection{Old Cairo: heritage and conservation events, 1798-1998}

1798-1801 Napoleonic Expedition occupies Lower Egypt

1800 Detailed map published of Cairo by Napoleon's Surveyors

1880 Comite de Conservation des Monuments de l'Art Arabe established 
1950 List of 622 'Islamic' monuments drawn up

1952 Comite de Conservation des Monuments de l'Art Arabe dissolved

1977 Association for the Urban Development of Islamic Cairo set up

1979 Old Cairo designated a World Heritage Site by UNESCO

$1980 \quad$ UNESCO Plan for Old Cairo produced

1988 Greater Cairo Region Master Plan included Old Cairo as part of Homogeneous Sector No. 1

1988-1991 GOPP/IAURIF Plans for rehabilitation of Sayeda Zeinab Quarter, Gamaliya Quarter and Darb al Asfar Quarter

1992 Earthquake damaged many monuments in Old Cairo

1997 UNDP Rehabilitation Plan for Old Cairo

1998-1999 Al-Azhar road tunnel constructed

Source: (K. Sutton, W. Fahmi / Habitat international 26 - 2002).

\section{OVERVIEW ON SOME NEW SPECIFIC PLANS FOR OLD CAIRO}

\subsection{The 1980 UNESCO Plan}

The late 1970 s saw UNESCO involvement through its promotion of an inventory of historic monuments by Michael Meinecke on the basis of which Old Cairo was then publicized as a significant concentration of medieval Islamic buildings (Posmowski, 1978). This was followed by the designation of Old Cairo by UNESCO as a World Heritage Site in 1979.

As a consequence, a team of architects, planners and conservators was assembled to draw up a new specific plan for Old Cairo that aimed to reverse the flight of the Old City's residential population and to advocate emergency action for its many decaying monuments (Antoniou et al., 1980).

The established list of 450 monuments to be protected in Old Cairo was to be strengthened and updated. The problem of overlapping authorities was bemoaned with no overall control or policy for the future development of the Old City. Public authorities were weak in comparison with commercial interests. Better traffic management was advocated in particular to reduce cross traffic. Six priority zones were defined within which new development would be restricted, old buildings would be restored and new compatible functions introduced.

The 1980 UNESCO Plan also suggested that planning and conservation proposals should be launched for adjacent historic areas including the Northern and Southern Cemeteries, the Fustat archaeological zone, the Coptic area and Bulaq. Social studies were advocated to gain a fuller understanding of the situation, problems and aspirations of the existing residential population of Old Cairo and the other historic zones.

Although this 1980 plan remained a 'paper project' and was not put into action, subsequent projects tended to be based on it and there was even some continuity in 
the consultants involved between the 1980 project and the 1997 UNDP Plan. The earlier efforts at restoring individual monuments continued in a piecemeal and uncoordinated way. A mosque here, a madrassa there, a sabil-kuttub (fountain) elsewhere were restored by both, Egyptian authorities and foreign agencies from a wide range of countries. The Italians restored the Mawlawi whirling dervishes theatre, the French restored some magnificent vernacular houses, the Royal Danish Academy of Fine Arts restored the Madrasa al-Jawhariyya next to the Al-Azhar mosque, and an Islamic order from India restored the major if dilapidated Al Hakim mosque in a somewhat controversial manner.

Rodenbeck (1983, p. 25) was critical of this restoration of the Al Hakim mosque, which, he suggested, has "given us instead a new building". This was despite its restoration, or rather reconstruction, being carried out with the advice of Hassan Fathy whose "aesthetics are charming, but have no basis in history".

Other countries and NGOs contributed to other such restoration efforts. While worthy in their own right, these scattered piecemeal contributions (only a handful of buildings out of the 500 buildings listed as important Islamic monuments) hardly added up to a planned conservation of the Old City. Rodenbeck $(1983$, p. 26) argued that to save monuments in isolation from their 'environment' (e.g. the urban fabric) was a sterile waste of time.

There was an urgent need to recapture Mameluk Cairo's "size, splendour and dynamism" in a more holistic way. In similar vein, Lewcock (1989, p. 8), in commenting on the 1980 UNESCO Plan, argued that "it was felt that it was the uniqueness of ensemble that was the real quality of Old Cairo.

Individually, the buildings are not all masterpieces, but collectively their character is strong and fascinating". Hence, he supported the focusing on six ensembles as 'conservation and rehabilitation' zones. In the event, however, the aim of conserving clusters of buildings "to preserve their essential ambience has not been adopted". Instead, emergency action was taken on a number of individual monuments including the Citadel and the Aqueduct.

An alternative approach, also put forward during the 1980 s for the Gamaliya area by Abdel Fattah and Abdelhalim (1989), advocated renovation through demolition. After suggesting that $35 \%$ of the built-up area should be upgraded plus any building over 100 years old, they argued that $60 \%$ to $65 \%$ of the buildings (excluding monuments) "must be regarded as ripe for redevelopment". This meant ready for demolition!

They further advocated greater traffic access to Old Cairo with more parking availability and considered that a certain amount of gentrification was inevitable, as it would produce economic returns. Evidently, the future of the Old City was still under threat. 


\subsection{The Greater Cairo Region (GCR) Master Plan 1988}

The development and upgrading of the Old City (categorised in the GCR Plan as Homogeneous Sector No. 1) aimed to preserve the traditional fabric through building control regulations combined with the development of open spaces and the improvement of its infrastructure including its street network through imposing restrictions on vehicle access.

In addition, the plan involved the development of public spaces in North Gamalia and Darb Al Asfar and the provision of mixed land uses aiming to improve the urban landscape. The conservation of monuments was prioritized with their reuse for various social and cultural activities, e.g. the Beit Al Sehimi in the Darb Al Asfar district (a restored 17 th-century house).

Furthermore, these proposals identified the need also to upgrade the surrounding built environment and to raise local people's awareness. Commercial activities were to be developed to promote the socio-economic and cultural role already played by the Old City as a tourist attraction. Subsequently the official policy was to transfer wholesale commercial and industrial activities to the eastern New Settlements, whilst keeping retailing and handicraft workshops within the main historical spine.

\subsection{General Organisation for Physical Planning (GOPP) and Institut d'Amenagement Urbain et Regional de 'Ille de France (IAURIF) Plans, 1988-1991}

The early 1990s saw three projects which did endeavor to encompass whole districts. Schemes to rehabilitate the Sayeda Zeinab Quarter in the south, the Gamaliya Quarter in the north and the Darb al Asfar Quarter in the east were drawn up by a joint French-Egyptian planning and research body namely the IAURIF/GOPPP.

This collaborative research body produced general guidelines for the improvement of the built environment. In particular, it sought to develop the northern and southern gates and to put in place a ring road around the Old City.

The Sayeda Zeinab Project included the relocating of noisome tanning and abattoir activities to less problematic sites on the periphery of Greater Cairo. What would replace these premises is rather vague according to Madoeuf (1995). The planners would try and re-orientate the district towards the city centre through improved communications and then leave development to private initiative having implanted some green spaces and public services. In its Darb Al Asfar Scheme the GOPP/IAURIF identified priority areas, such as Beit El Sehime, a house constructed in 1648 , and the house of Mostafa Ga'afar, built in 1713, for action plans.

These areas were determined according to the significance of monuments capable of upgrading and developing and according to the predominant commercial activities and their land use patterns. Policy guidelines stressed the rehabilitation of the urban fabric, the development of public spaces, and the transferring of industrial activities 
out to surrounding settlements such as Manshiet Nasser. Then followed the redevelopment of housing and public services such as sewers and garbage disposal systems plus the introduction of tourist facilities, including a youth centre and hotels (Edward, 1998).

The North Gamalia district of Old Cairo had population densities reaching $600-800$ persons/ha, all within an increasingly derelict and decaying urban area with environmentally damaging industries. The GOPP/IAURIF research team in 1990 recommended the creation of a new boulevard along the city walls in order to facilitate access to the Old City together with the development of open spaces and the landscaping of certain areas.

The Gamaliya Project (Madoeuf, 1995) aimed to rehabilitate 60 ha, half of which constituted the old cemetery of Bab al-Nasr just north of the Fatimid Walls, which themselves were to be restored and freed of their accompaniment of lean-to shanties (Edward, 1998). The cemetery partly occupied by squatters was to be transformed into a park but keeping some significant tombs such as that of Ibn Khaldoun. However, this never occurred as a result of disputes over compensation to cover the evacuation and demolition of the tombs.

More controversially was a proposed development containing two luxury tourist hotels and a commercial centre in the form of a new souk, modeled on the Khan-elKhalili bazaar area to the north of Bab el Futuh. In general terms, the Gamaliya Project sought to emphasise the creation of public spaces in front of monuments such as the Fatimid walls, but this approach was not a traditional Islamic concept with respect to urban organization and layout. Salin (1996, pp. 83-86) is quite critical of the over-orientation towards international tourism on the part of the North Gamalia Project. She argues that the social improvement aspirations of the IAURIF's French urbanists have been somewhat forgotten in the tourism-dominated GOPP Plan. A four-star tourist complex has little relevance in a zone of low class housing. An urban museum situation is threatened with a segregated space orientated more to tourists than to the original inhabitants.

Indeed, many of the residents would be re-settled in the new settlements on the fringe of Greater Cairo as, according to Madoeuf (1995), 500 dwellings and 280 businesses would disappear to be replaced by 1000 apartments and $10,500 \mathrm{~m}^{2}$ of shopping space.

However, there certainly was a need to improve living conditions through upgrading services and creating public spaces whilst also reducing traffic congestion. In addition, 10 ha of industrial zone were to be redeveloped as part of the rehabilitation strategy, which proposed the relocation of small industrial units to new settlements east of Cairo. The newly created areas within the Old City were to be used to improve the street network and to introduce some open spaces, parking areas and community services. The reuse and renovation of historic buildings revitalizes the surrounding public open spaces. Hence the GOPP/IAURIF rehabilitation strategy proposed to enhance both the historic buildings and their 
urban environment through the introduction (wherever possible) of new public spaces that would serve to set off the monuments to better effect. Somewhat in the style of European plazas, this objective would be achieved through removing various encroaching buildings and through pedestrianization and traffic control measures. Parking would be kept away from the historical monuments.

Figure (3) UNDP Rehabilitation Plan, 1997

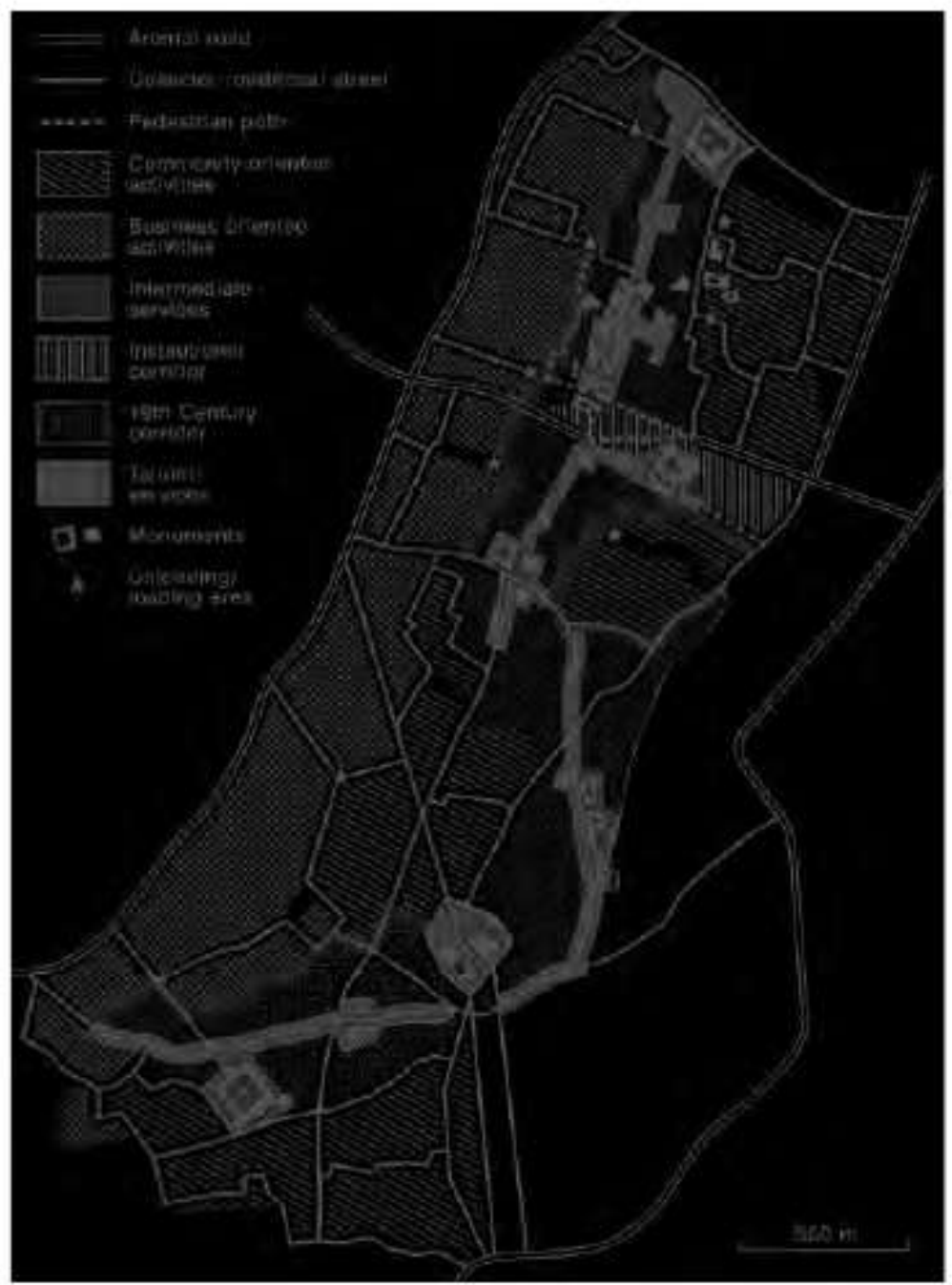

Source: after UNDP (1997)

\subsection{The 1997 UNDP Rehabilitation Plan}

The most recent plan for Old Cairo was drawn up by a UNDP team which interestingly included Jim Antoniou, a British architect who had earlier been part of the 1980 UNESCO team. The 1997 plan covers an area of about $4 \mathrm{~km}^{2}$ in Old Cairo from Bab el Futuh in the north to the Ibn Tulun mosque in the south. The area so delineated contained about 310,000 inhabitants in 1986 which represented a sharp drop from its 1966 population of 433,000 . In seeking to achieve a broad-based rehabilitation, the plan combines two contrasting approaches. Firstly, it advocates a 
tourism-based rehabilitation to restore and reuse monuments. It aims to attract in investment to restore significant buildings and then reuse them for business and even housing so involving some limited gentrification. The squatters in such old monuments would be re-settled but not in the building in question. Vacant plots would be developed for recreation purposes, services and facilities for the gentrified communities.

This approach would ensure the protection of monuments up to a certain extent arguing that such preservation cannot be trusted to private investment and tourism without close supervision. With the re-settlement of some of the urban poor, the vibrant community atmosphere so redolent of Old Cairo would partly be lost.

Secondly, the plan also advocates parallel community-based rehabilitation to benefit primarily the poorest amongst the present residents. This rehabilitation exercise would restore and improve local residents' housing and empower the local community as their education and skills are improved, their built environment is upgraded, and local social services are ameliorated. Monuments would be restored and reused for social services and other community functions. New projects, such as using vacant land to lodge the homeless and squatters, would be labor-intensive to provide local jobs. Cost recovery would not be ensured and few profit-generating opportunities would exist for private investors in this approach to rehabilitating the community as well as its built environment.

To overcome the resource gap it is expected that cross-subsidization would occur from the first private capital funded approach to this second community rehabilitation. In this way, a broader-based rehabilitation would attempt to achieve both the above rehabilitation objectives. So, there is a degree of compromise in the UNDP Plan as can be seen in Fig.3. The Heritage Corridor represents the first rehabilitation approach focused on business interests and tourists. The blocks of community orientated activities located on either side of the Heritage Corridor represent the second approach.

The plan uses a 'clusters approach' and identifies nine clusters of historic monuments, each being a primary target for rehabilitation, upgrading and conservation. Monument reuse would serve the community (through social services), the business sector (through licences for private sector use), and the tourist industry (through reuse as museums, information centers, etc.). The streets linking these clusters of monuments would be regarded as equally important as they provide continuity of traditional activities between the clusters. Together, the clusters and their linking streets make up the Heritage Corridor identified in Fig.4.

Interestingly, six of the clusters had been similarly identified in the 1980 UNESCO study, exemplifying continuity between plans. Other pertinent aspects of the 1997 plan include the pedestrianization of the central spine, along Al-Mu'izz Street, and some other streets, at least between 9.00 a.m. and 9.00 p.m. Also, one-way streets would be introduced to ease traffic congestion. Several loading/unloading areas are planned linked to the outside road system. 
Figure (4) Monuments clusters and heritage corridor UNDP Plan

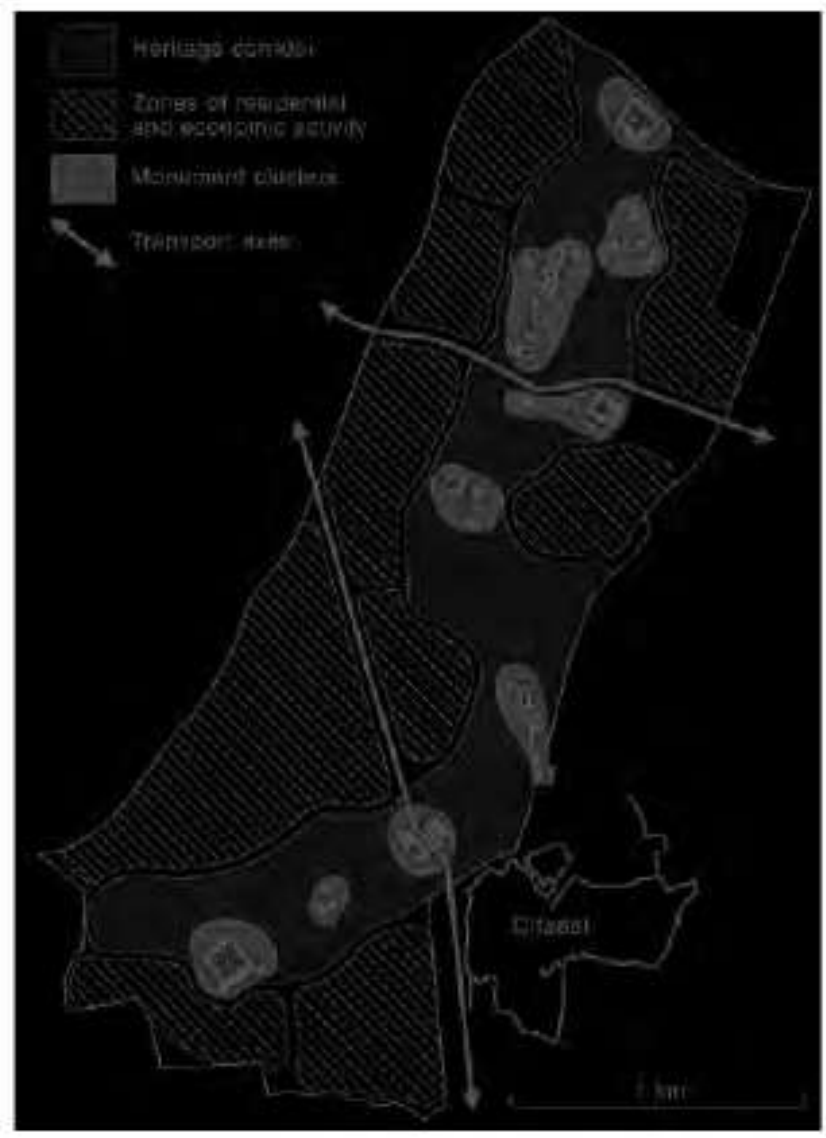

Source: after Al-Futuh (1998)

A vacant-land tax would seek to encourage development on hitherto unused and abandoned plots. A key contribution could be the advocated "adaptive reuse" (UNDP, 1997, p. 85) of restored buildings with the suggestion that a significant sabilkuttub (former fountains and Koranic schools combined) be used as a tourist information centre. Interestingly, the plan also aims to resurrect the old 'al-fina' concept whereby shops and workshops can extend their activities out on to the street in front of their premises. So, as in days gone by, streets in Old Cairo would again consist of central public space for pedestrians and traffic and semi-private space that can be used by local residents for trading and other uses. While this UNDP Plan was originally produced in 1997, it has yet to be comprehensively put into action. Indeed, the UNDP consultancy team anticipated a lack of action, probably in the light of earlier experience with the Cairo and Egyptian Government authorities.

The consultancy team quite frankly stated that without a proper organisation to implement their suggestions "the considerable resources devoted to the project will likely come to nought, at least in terms of action on the ground" (UNDP, 1997, p. vii). The team considered that the current (1997) situation was acute enough to necessitate immediate action on a large enough scale to save the fabric of historic Cairo and its many monuments. The alternative to taking such action would be to 
relinquish the historic core to vested interests and only to concentrate on saving a few individual monuments.

The UNDP report considered that "such an outcome would be a major loss for Egypt and the whole world" (UNDP, 1997, p. viii). A related problem is the establishment of an appropriate authority like the Association for the Safeguard of the Medina in Tunis, focused on Old Cairo and managing its heritage conservation. The UNDP report (1997, p. 151) does suggest a very hierarchical organization dependent on the Egyptian Government ministries and hardly involving local people at all, whereas a bottom-up NGO would probably be preferable. Political considerations, however, would undoubtedly exclude the latter approach to management. So, Old Cairo now has a promising plan based largely on the principles of rehabilitation rather than just restoration. But action on Old Cairo's safeguarding remains limited to the piecemeal restoration of a limited number of its monuments and to a few demonstration projects. The ideas are there but the will power, organization and funding are lacking and more of the historic monuments and the important built environment of this medina area are likely to disappear and crumble.

\subsection{Late 1990 s planning activities in Old Cairo}

Despite the availability of an overall 1997 Rehabilitation Plan, the government has pursued its own separate conservation policies during 1998 and 1999. Given its tourist potential, Al Azhar square was considered a priority area by government officials. Furthermore, the Al Azhar road bridge presents visual problems and the associated traffic has environmental consequences for the locality's historical monuments. So, resources are being invested in what amounts to one of the most significant projects so far to upgrade Old Cairo. After two years devoted to the restoration of the Al Azhar and Al Hussein mosques, the locality's cultural role as the focus of the Al Mu'izz Street main spine and the Khan Al Khalili bazaar area came to be considered as threatened by the east-west road axis and road bridge; therefore, a road tunnel under the Al Azhar area and associated underground parking, form the next stage of the Al Azhar Project. As a result, the area between the two mosques will now be transformed into a new plaza which would directly have access to the central spine of Al Mu'izz Street which itself would be pedestrianised (walk street). Traffic would be diverted largely on to an inner ring road around the Old City.

\section{WHY AIRBORNE LASER SCANNING}

All the different rehabilitation plans and their impacts are could better understand and discussed, if visualized in 3D. Even the setting up of any of the plans could be support by recent maps, preferably in 3D. As the need of up to date 3D information was obvious, in 1996 the idea came up to produce a elevation model of a part of Cairo by means if airborne laserscanning (ALS).

Basic benefits expected from ALS and the generated DEM were: 
- actual, consistent 3D information on structure of a larger part of the city (also as realistic input for future rehabilitation plans)

- quick availability of the digital elevation model DEM (only weeks after the survey flight)

- get a means to measure building heights and calculate from this information the number of inhabitants in a certain area

- demonstrate the capabilities of ALS in order to use this technology more frequently in Egypt in future.

\section{ISLAMIC CAIRO “ALS" DATA}

\subsection{About ALS technology}

At that time it was decided to use the laserscanning system of TopoSys $\mathrm{GmbH}$, Germany for the survey (Fig. 5). In 1996 laserscanning was just on the way to demonstrate its capabilities, while nowadays Laserscanning is accepted as an operation tool for fast generation of accurate 3D information. General information on laserscanning technology and its use can be found at e.g. Wehr (1999) and Lohr (2005).

Figure (5) Laser Equipment

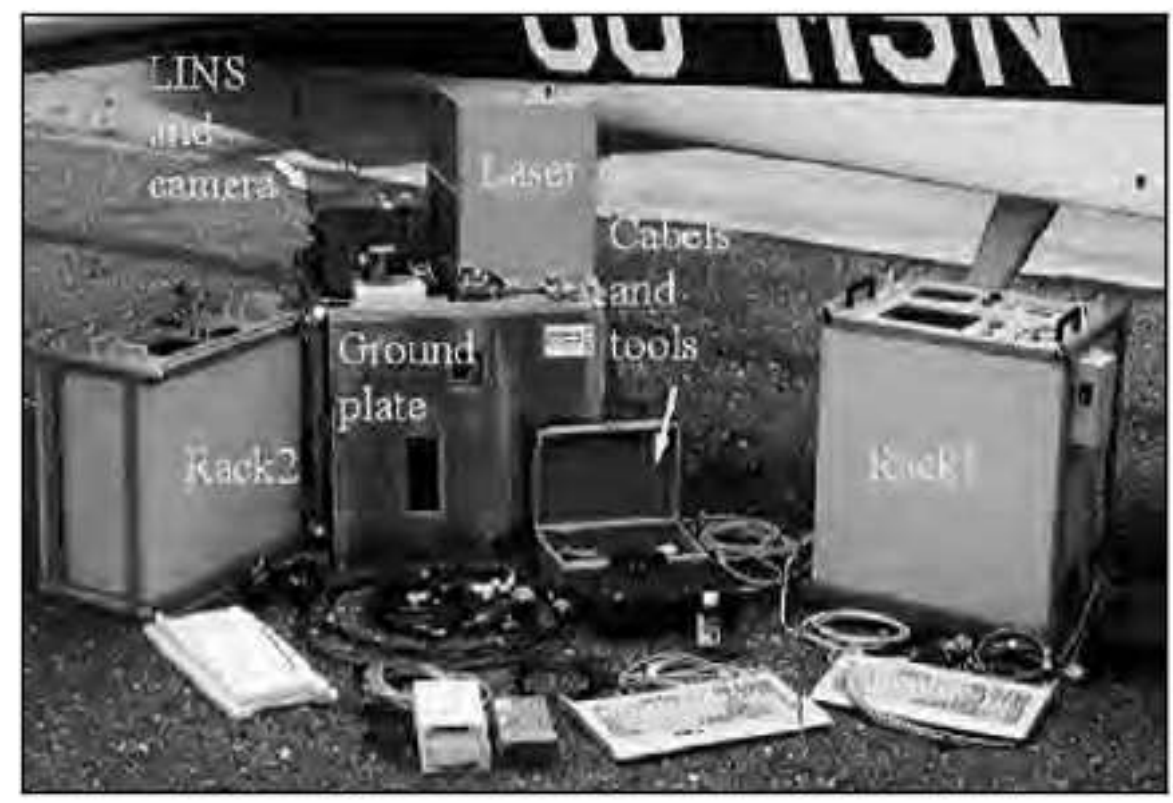

Source: TopoSys GmbH 1998

Installed in a Kingair aircraft of NARRS, the survey area was scanned with a high point density of about 4 laser measurement points per $\mathrm{m}^{2}$. Due to its small scan angle of in total about $14^{\circ}$, the laser scanner system was able to receive information from street level even in this dense building structure (frequently the width of streets do not exceed 3 meter). From laser measurements, dGPS and LINS data a $1 \mathrm{~m}$ raster elevation model of the district was generated providing an accuracy of $15 \mathrm{~cm}$ in height and $50 \mathrm{~cm}$ in position. 


\subsection{Examples of Islamic Cairo}

The following pictures show different views of the elevation model produced in the campaign (July 1999).

Figure (6)

Part of pseudo-colored ALS data of El-Hakim district in Islamic Cairo

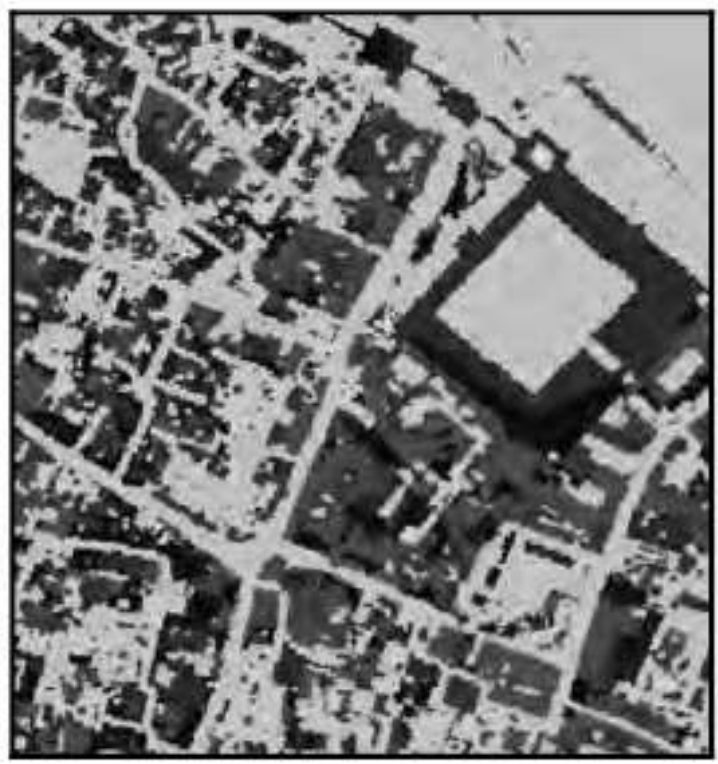

Source NARSS ALS project 1999

Figure (8)

Vectorizing buildings of

El-Hakim district in Islamic Cairo

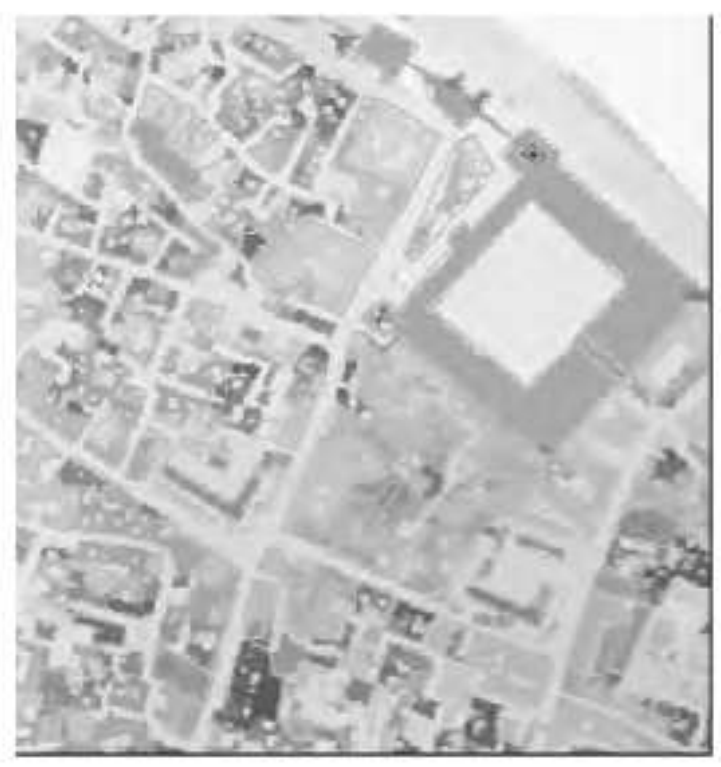

Source NARSS ALS project 1999
Figure (7)

Part of grey-shaded ALS data of

El-Hakim district in Islamic Cairo

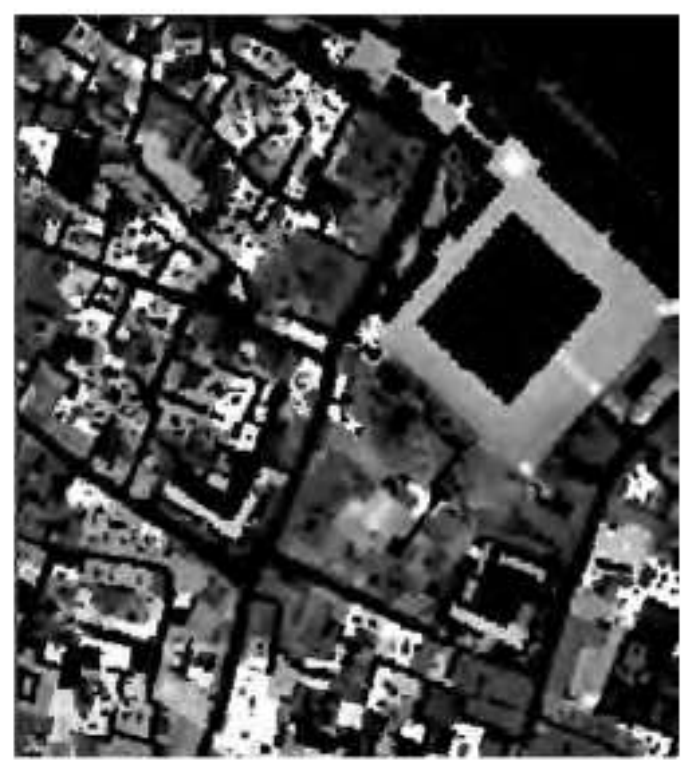

Source NARSS ALS project 1999

Figure (9)

Part of pseudo-colored ALS data of Manshit Naser unofficial district behind old Cairo

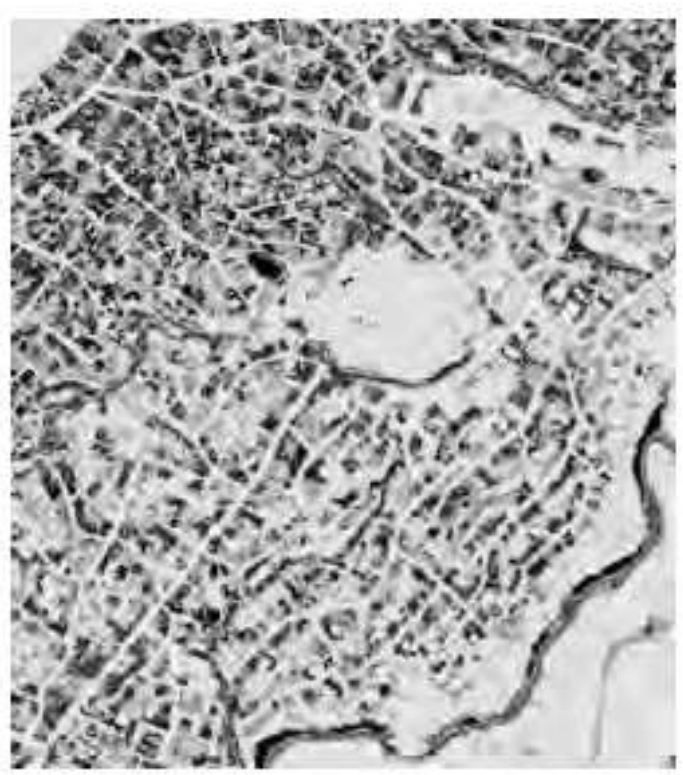

Source NARSS ALS project 1999 
Figure (10) 3-D view of ALS data of the Manshit Naser unofficial district behind old Cairo

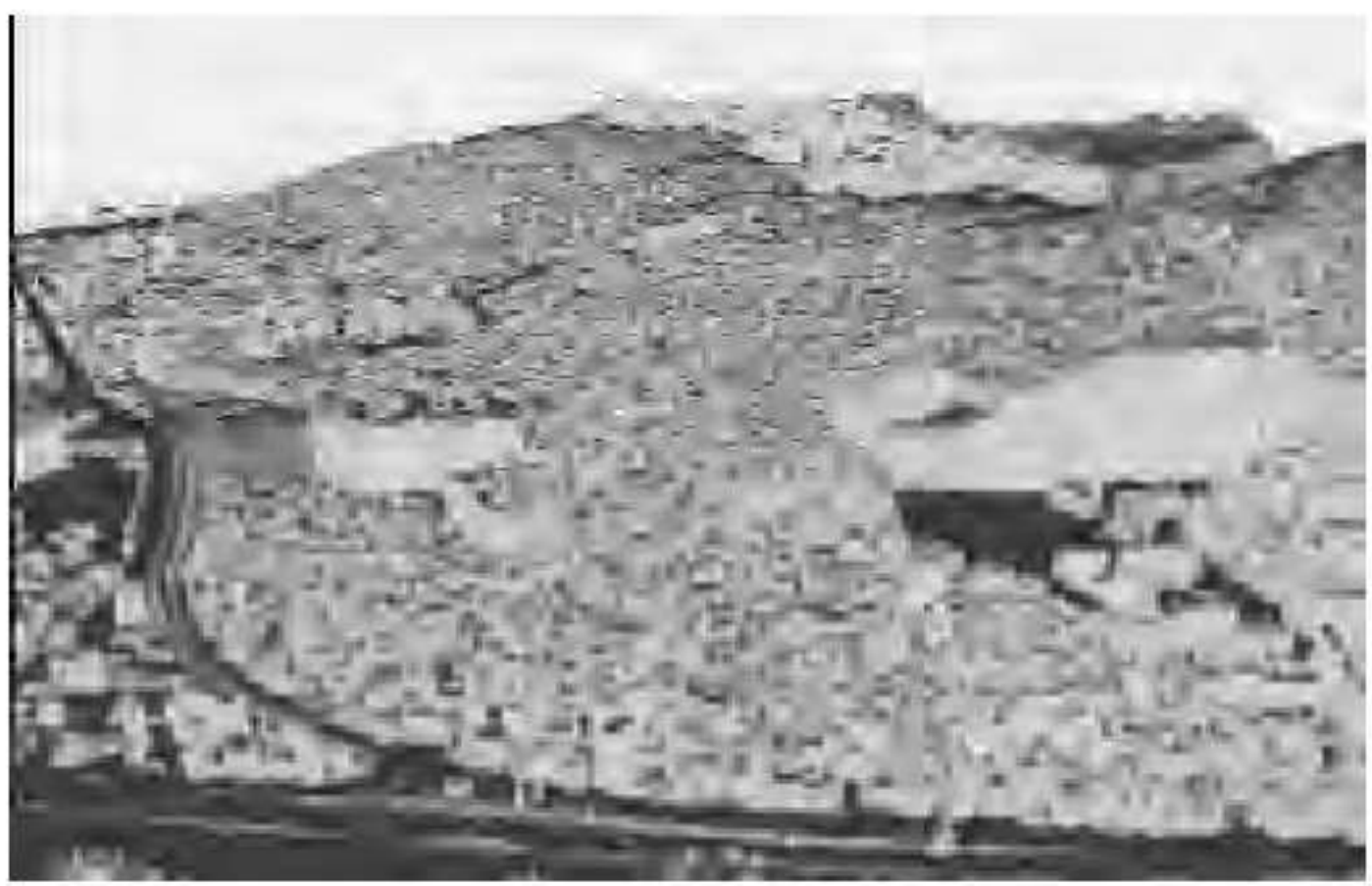

Source NARSS ALS project 1999

\subsection{Further potential use of ALS data}

Beside of rehabilitation of city centers, the need for virtual 3D city models is rapidly growing for applications like city planning and development, location marketing and tourism, car navigation, disaster management (Lohr, 2004).

For the presentation of 3D models, a powerful and flexible 3D visualization and navigation system is essential - not only for showing the data. Sometimes, an attractive presentation is the central key to convince involved parties and decision makers of a specific intention (e.g. to illustrate the design of a new building in an existing environment).

For the purpose of presentation, laserscanning DEM (like that of Cairo) may be vectorized also to reduce the amount of data. Nowadays, vectorization can be done very efficiently and in a cost effective manner as there are tools commercially available (Brenner, 2000). After vectorization, the 3D building structure may be draped with photographs in order to give a realistic appearance (see Fig. 11).

Depending on the kind of visualization software, 3D-building may e.g. be replaced by new buildings generated in some architectural CAD software. In this manner single building or even a complex of planned buildings may be put into the model to replace existing building in order to show the appearance of e.g. a planned rehabilitation. 
Figure (11) Part of the 3D city model of Parma, Italy (C) ReallT, Germany

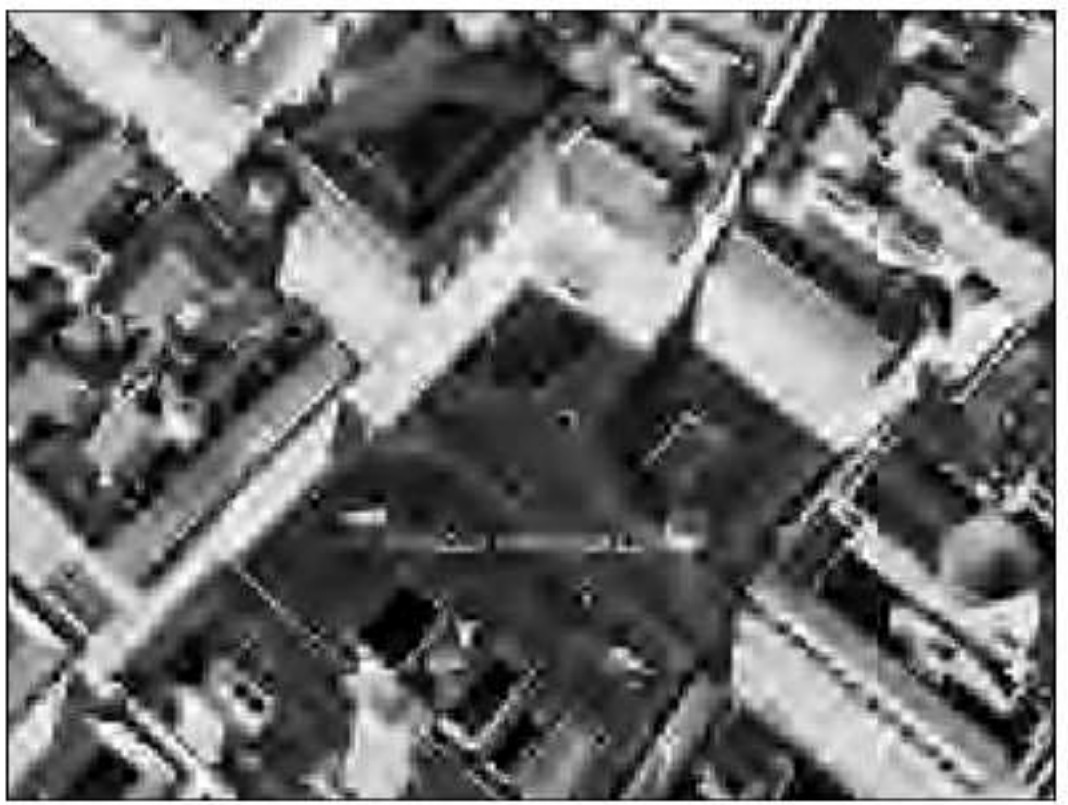

\section{CONCLUSION}

We can say that in Islamic Cairo conservation and planning approaches have fallen into three main categories:

\section{a. Restoration:}

This approach concentrated on restoring the monuments or significant buildings, from palaces to mosques and including old traditional-style houses which exemplify vernacular architecture. The result can be to produce a 'museum town', for tourists rather than for residents.

\section{b. Renovation:}

This approach may be necessary if buildings in the medina collapse and have to be cleared. But renovation has become associated with demolition and may not always result in rebuilding in traditional vernacular architectural styles.

\section{c. Rehabilitation:}

This approach seeks to rehabilitate the old city society and economy as it is now, or as it recently was, and does not aim to recreate the past. Rehabilitation can and indeed ought to involve the participation of the medina's residents in decision making about their quarter and even in actively improving its buildings.

Despite the availability of the 1980 UNESCO Plan and the 1997 UNDP Plan for Old Cairo's rehabilitation, government policies remain insufficient and fragmentary with a tendency to favor tourist-orientated projects. The local population's attitudes and potential participation remain largely ignored. 
From what we shown in this paper as a work in one of the biggest and oldest Heritage City (Cairo) it is really very useful to use the Laser data in the upgrading planning process. This data provides very accurate information and moreover, it is also 3D data (DEM).

ALS data is more easy, faster (days) and accurate compared to another ordinary aerial photography technique (month's). The decision maker nowadays needs this type of data, which is compatible with the GIS programs, to make his spatial analyses.

ALS is modernist recent remote sensing technique. We can use it in digital type with another data so easy to create 3D city model.

ALS German system (TopoSys) is now (2001-2002) in Egypt. The expert's decision in NARSS after this pilot or test project (1999) was to buy this system because the benefits in technique and price are not to compare. This is totally another state of art. In technique we have digital data in 3D (DEM) and in time we save many weeks. In civil work the western world use this technology only from few years (1994-1995). Maybe NARSS after they use it in some projects we can in Egypt have the price list.

\section{References}

Aboukorah, O. (1995). Espace d'habitat et espace de travail "a Darb al-Ahmar. Lettre d'Information de l'Observatoire Urbaine du Caire Contemporaine, 39, 11-20.

Abu-Lughod, J. (1971). Cairo. 1001 years of the city victorious. Princeton, NJ: Princeton University Press.

Ahmed, H. F., \& Kamel, B. (1996). Cairo: Three cities, three periods, three maidans. Built Environment, 22(2), 104-123.

Antoniou, J., Welbank, M., Lewcock, R., and El-Hakim, S. (1980). The conservation of the old city of Cairo. London: UNESCO. 2 Vols.

Brenner, C., (2000). Towards Fully Automatic Generation of City Models. IAPRS Vol. XXXIII, Part B3/1, Comm. III, ISPRS Congress, Amsterdam, pp. 85-92,.

Description de l'Egypte (1809). Imprimerie Imperiale. Paris. Dix, G. (1990). Conservation and change in the city. Third World Planning Review, 12, 385406.

Edward, H. (1998). Conference donnee par Hoda Edward dans le cadre du 25"eme anniversaire du GOPP (General Organisation for Physical Planning) le 27/04/98 au Centre Francais de Culture et de Cooperation. Lettre d'Information de l'Observatoire Urbaine du Caire Contemporaine, 48, 40-47.

Fathy, H. (1973). Architecture for the poor: An experiment in rural Egypt. Chicago \& London: University of Chicago Press. 
Ilbert, R. (1982). Le Caire a-t-il un medina? Publications de l'Equipe de Recherches Associ ee (No. 706). Fascicule de Recherches (No. 10-11, pp. 263-281). Tours: Institut de Geographie.

Lewcock, R. (1989). Conservation in Islamic Cairo. In The Aga Khan Award for Architecture. The expanding metropolis: Coping with the urban growth of Cairo (Vol. 1). (Conference papers).

Lohr, U. (2004), Precise LIDAR data - an efficient way to build up virtual 3D city models, at International Workshop on Vision Techniques Applied to the Rehabilitation of City Centres organized by CIPA, Lisbon, Portugal.

Lohr, U. (2005), Capabilities and applications of airborne laser scanning, at ISPRS Int. Conference on Advanced Remote Sensing for Earth Observation, Riyadh, KSA.

Madoeuf, A. (1997). Image et pratiques de la ville ancienne du Caire: Les sens de la ville. Lettre d'Information du Observatoire Urbaine du Caire Contemporaine, $47,6-15$.

Meyer, G. (1988). Manufacturing in old quarter of Central Cairo. In URBAMA, Elements sur les Centre-villes dans le Monde Arabe. Fascicule de Recherches (No. 19, pp. 75-90). Tours: URBAMA.

Meyer, G. (1990). Wirtschaftlicher und sozialer Strukturwandel in der Altstadt von Kairo. Erdkunde (44), 93-110.

Posmowski, P. (1978). Le Caire Islamique: un tresor "a sauvegarder. Information's UNESCO, 738, 6-16.

Rodenbeck, J. (1983). Urban conservation: its realities and the role it offers social research. In R. Lobban (Ed.), Urban research strategies for Egypt. Cairo Papers in Social Science (Vol. 6 (2), pp. 22-34). Cairo: American University in Cairo Press.

Salin, E. (1996). Les Quartiers Historiques du Caire et de Mexico: representations de l'espace, mutations urbaines et protection de patrimoine. Memoire de DEA. University of Paris X-Nanterre.

Schreur, E. (1999). National heritage Cairo style. ISIM Newsletter (International Institute for the Study of Islam in the Modern World), 2, 18.

Signoles, P. (1988). Place des Medinas dans le Fonctionnement et l'Amenagement des Villes au Maghreb. In Elements sur les Centre-Villes dans le Monde Arabe (pp. 231-271). Fascicule 19. Tours: URBAMA.

El-Shakhs (Eds.), Urban development in the Muslim world (pp. 94-108). New Brunswick, NJ: Centre for Urban Policy Research.

Sutton, K., Fahmi, W. (2002), The rehabilitation of Old Cairo. Habitat International 26 (2002) 73-93

UNDP (United Nations Development Program) (1997). Rehabilitation of historic Cairo. Final report. Cairo: UNDP Technical Cooperation Office

Wehr, A., Lohr, U., 1999. Airborne Laserscanning - an introduction and overview, ISPRS Journal of Photogrammetry and Remote Sensing, 54, pp. $68-82$ 